\title{
Optimization of a viability-PCR method for the detection of Listeria monocytogenes in food samples
}

Gemma Agustí $^{1 *}$, Mariana Fittipaldi ${ }^{2}$, Francesc Codony $^{1}$

${ }^{1}$ GenIUL, Carrer de la Ciutat d'Assunción 4, 08030 Barcelona, Spain.

${ }^{2}$ Laboratori de Microbiologia Sanitària i Mediambiental (MSM-Lab), Universitat Politècnica de Catalunya, Edifici GAIA, Rambla Sant Nebridi, 22. 08222. Terrassa, Barcelona, Spain.

* Corresponding author: Gemma Agustí (gagusti@geniul.com)

\begin{abstract}
Rapid detection of Listeria and other microbial pathogens in food is an essential part of quality control and it is critical for ensuring the safety of consumers. Culture-based methods for detecting foodborne pathogens are time-consuming, laborious and cannot detect viable but non-culturable microorganism, whereas viability PCR methodology provides quick results; it is able to detect viable but non-culturable cells, and allows for easier handling of large amount of samples. Although the most critical point to use viability PCR technique is achieving the complete exclusion of dead cells amplification signals, many improvements are being introduced to overcome this. In the present work, the yield of dead cell DNA neutralization was enhanced by incorporating two new sample treatment strategies: tube change combined with a double light treatment. This procedure was successfully tested using artificially contaminated food samples, showing improved neutralization of dead cell DNA.
\end{abstract}

Keywords: propidium monoazide, viability PCR, live-dead distinction, Listeria monocytogenes, foodborne pathogen detection 


\section{INTRODUCTION}

Listeria monocytogenes is one of the most virulent foodborne pathogens. It is a Gram-positive and facultative anaerobic bacterium, which is capable of growing and replicating inside the host's cells. This bacterium causes listeriosis, the third-leading cause of death among foodborne bacterial pathogens, with fatality rates exceeding even Salmonella and Clostridium botulinum [19].

Listeria is commonly found in dairy products, meat, poultry, and seafood. Foods that are ready to eat, require refrigeration, and if are stored for an extended period of time have a higher likelihood of contamination than other products. L. monocytogenes has the ability to adapt to a wide range of conditions and survives in stressful environments, such as nutrient starvation, low refrigeration temperatures and osmotic and oxidative stress $[2,12]$. To prevent Listeria infection and guarantee consumer safety, the control of this bacterium is required. Cell culture is the commonly performed method for detection and isolation of L. monocytogenes according to the U.S. Food and Drug Administration (FDA) specifications [7].

The culture approach is a time consuming methodology. Standard methods for detection of $L$. monocytogenes by culture at levels lower than $100 \mathrm{CFU} \mathrm{g}^{-1}$ require at least $48 \mathrm{~h}$. As a first step, a primary selective enrichment (24h) is needed, followed by plate isolation (24h) and in some cases (depending on each analytical standard) by a biochemical confirmation step. Although the isolation with differential media can be done with the primary enrichment, according to the International Organization Standardisation (ISO) method (UNE-EN ISO 11290-1:2017) [21], it is also necessary an additional secondary enrichment in order to ensure a complete cell growth. Moreover, this method presents other limitations such as the inability to detect viable but non-culturable (VBNC) cells [26] and detection difficulties as result of the possible presence of other Listeria species that usually outgrow and mask $L$. monocytogenes detection.

Listeria direct enumeration by plating on selective and differential agar plates, can only be done in samples in which high levels of Listeria cells are suspected to be present (>100 CFU g $\left.{ }^{-1}\right)$. On the other hand, the quality criterion from some CE rules (CE 1441/2007) specifies the absence of the pathogen in $25 \mathrm{gr}$ in certain foods. Under this scenario, it is highly likely that in the majority of the cases previous culture enrichment be necessary before any detection method can be applied. 
The development of more rapid and sensitive methods for the detection and quantification of viable $L$. monocytogenes cells is essential for monitoring food quality and listeriosis prevention [14], but also for extending commercial life of short-term food products. In order to cover these needs, new methods using PCR techniques have been developed $[3,15]$. PCR techniques allow quick results, the detection of VBNC Listeria cells, easier handling of large samples and, moreover, fit perfectly with the current workflows, such as being applicable after the primary enrichment. In this case the L. monocytogenes absence can be confirmed in 24h. However, PCR detects DNA in both live and dead cells and, as a consequence of this, it typically overestimates the quantity of infectious Listeria cells. Among other molecular strategies, viability PCR (v-PCR) and RT-PCR methods have been proposed as alternatives to culture-dependent procedure to discriminate between dead and viable cells [6, 24].

The v-PCR is based in the use of photo reactive DNA-intercalating agents, like ethidium monoazide (EMA), propidium monoazide (PMA) and PEMAX ${ }^{\mathrm{TM}}$, which can only penetrate membrane-damaged cells and neutralize DNA by the means of light treatment. The application of this sample treatment in conjunction with PCR, allows for the detection of viable bacteria. V-PCR methodology has been assessed to detect viable $L$. monocytogenes by several authors $[5,8,17,18]$ but with drawbacks, the problem of false-positive results being the most important among them. This issue hinders results interpretation, especially in the analysis of complex samples [10].

The DNA neutralization from dead cells, without affecting live cells is the common challenge when a new v-PCR procedure is developed. Different researchers have followed diverse strategies for improving the procedures and overcome this bias. Up to now, most of the attention is focused on dye selection, incubation time, dye photoactivation exposure, reaction buffer composition, and PCR amplicon size [9]. In addition, the impact of the microtube on the v-qPCR analytical bias has been recently demonstrated [1].

In this work, a new scheme which combines a tube change procedure with a double light treatment was explored as a strategy for obtaining an optimum L. monocytogenes qualitative real-time v-PCR method. Aiming at developing an improved methodology to exclusively detect live Listeria cells in different food matrices, while avoiding time-consuming tasks and limitations of culture based methods. The performance of this novel approach was evaluated using artificially contaminated food samples. 


\section{MATERIAL AND METHODS}

\section{Bacterial inoculums}

L. monocytogenes (CECT 4032) was incubated at $37^{\circ} \mathrm{C}$ for 24 hours on PCA medium (Liofilchem, VWR, Barcelona, Spain). Bacterial cells were harvested from the agar plates and diluted in sterile phosphatebuffered saline (PBS 1X, pH 7.4) to obtain a working bacterial suspension. The cell density was adjusted to an OD600 of 0.30 , corresponding to $5.0 \times 10^{8}$ cells $\mathrm{ml}^{-1}$.

To obtain dead cells stocks, working bacterial suspension was heated at $85^{\circ} \mathrm{C}$ for $35 \mathrm{~min}$ using a standard laboratory heat block (Termomixer comfort, Eppendorf, Hamburg, Germany) and stored at $-20^{\circ} \mathrm{C}$ until use. Dead cells were plated on PCA medium in order to ensure the non-viability of the cells.

\section{Optimization of the viability dye treatment}

To assess the effect of photoactivation conditions and the impact of microtubes changes on v-qPCR, three different approaches were evaluated with live and dead cells stocks $\left(5.0 \times 10^{7} \mathrm{CFU}\right.$ sample $\left.{ }^{-1}\right)$ :

Treatment 1 , Single light treatment without change of tube.

Treatment 2, Single light treatment and double change of tube.

Treatment 3, Double light treatment and double change of tube.

Two independents experiments were carried out, and in each case treatments were evaluated by duplicate.

\section{Viability dye treatment}

PMA dye (GenIUL, Barcelona, Spain) was resuspended in PCR grade water (VWR) to obtain stock dye solution of $2 \mathrm{mM}$. It was dispensed into dark tubes and stored at $-20^{\circ} \mathrm{C}$ until needed.

$500 \mu \mathrm{l}$ of sample aliquots were centrifuged at $14,100 \times \mathrm{g}$ for $5 \mathrm{~min}$, and the cell pellets were resuspended in PBS at a final volume of $500 \mu \mathrm{l}$. PMA stock solution was added to the samples, to obtain a final dye concentration of $50 \mu \mathrm{M}$. Samples were incubated in the dark at $24^{\circ} \mathrm{C}$ for 30 min to allow dye penetration into dead cells with damaged membranes. After incubation in the dark, the samples with Treatment 2 and 3 were totally transferred to a new tube. Samples with Treatment 1 were kept in the same tube. All samples were then exposed to light treatment, single (15 min of light) or double (15 min of light $+10 \mathrm{~min}$ of darkness +15 min of light) using PhAST Blue system (GenIUL) at 100\% intensity. After photoactivation, samples with Treatment 2 and 3 were transferred again to a new tube. Samples with 
Treatment 1 were kept in the same tube. The samples were subsequently centrifuged at $14,100 \times \mathrm{g}$ for 5 min and the supernatant was discarded. In addition, $500 \mu 1$ of control samples untreated with PMA dye were concentrated by centrifugation and the supernatant was discarded.

\section{DNA purification and qualitative real-time PCR assay}

DNA was extracted using the v-DNA reagent (GenIUL), according to the manufacturer's instructions. Briefly, the cell pellets were resuspended in $200 \mu \mathrm{l}$ of v-DNA reagent (GenIUL) and were vortexed at 3,200 rpm for 5 min using multiplate shaker (Biosan, Riga, Latvia). Then, the cells were incubated at $80^{\circ} \mathrm{C}$ for $10 \mathrm{~min}$ at 1,200 rpm using a heat block (Termomixer comfort, Eppendorf). Then, $600 \mu \mathrm{l}$ of vDNA buffer (GenIUL) were added and samples were vortexed again at 3,200 rpm for 2 min. Thereafter, they were centrifuged at 7,500×g for $2 \mathrm{~min}$ and $100 \mu \mathrm{l}$ of supernatant were transferred to a new tube. Following DNA purification, the samples were analysed by qualitative real-time PCR.

For L. monocytogenes detection, a PCR procedure previously described by D'Agostino et al. [4] was adapted. Reactions were performed in the PikoReal ${ }^{\mathrm{TM}}$ real-time PCR system (Thermo Fisher Scientific, Massachusetts, USA) with the following real-time PCR cycling conditions optimized previously (data not shown): $12 \mathrm{~min}$ at $95^{\circ} \mathrm{C}, 45$ cycles of $10 \mathrm{sec}$ at $95^{\circ} \mathrm{C}, 20 \mathrm{sec}$ at $60^{\circ} \mathrm{C}$, and $20 \mathrm{sec}$ at $72^{\circ} \mathrm{C}$ followed by data acquisition, and finally a melting temperature (Tm) ramp from $65^{\circ} \mathrm{C}$ to $95^{\circ} \mathrm{C}$ at $0.2^{\circ} \mathrm{C} \mathrm{s}^{-1}$. All reactions were performed at a final volume of $20 \mu \mathrm{l}$ and contained $4 \mu \mathrm{l}$ of $5 \mathrm{x}$ HOT FIREPol ${ }^{\circledR}$ Evagreen ${ }^{\circledR}$ qPCR Supermix (Solis BioDyne, Tartu, Estonia), $5 \mu \mathrm{l}$ of DNA template and $0.25 \mu \mathrm{M}$ of primers. The primers according to D'Agostino et al. [4] amplified a 274 bp fragment of the prfA gene. Negative control, water PCR grade (VWR), and positive control, DNA from L. monocytogenes, were included in each qualitative real-time PCR assay. PCR inhibitions were evaluated by melting curve analysis and Tm value.

\section{Food Samples Handling}

A total of 26 commercial processed foods were purchased from local markets. The samples were not tested for Listeria before artificial speaking. For each food, $10 \mathrm{~g}$ were mixed with $90 \mathrm{ml}$ of Half Fraser broth (Reactivos para diagnóstico, Barcelona, Spain) into a sample filter bag (IUL S.A., Barcelona, Spain). This amount was chosen taking into account the ratio (1:9) specified in the ISO regulation (UNEEN ISO 11290-1 (2017) [21]. Then, live and heat-treated L. monocytogenes cells at 1.0-5.0 $\times 10^{1}$ and 1.0 $5.0 \times 10^{7} \mathrm{CFU} \mathrm{\textrm {g } ^ { - 1 }}$ respectively, were spiked into food suspensions and homogenized for $30 \mathrm{~s}$ in a paddle 
blender homogenizer (Masticator, IUL). $100 \mathrm{ml}$ of Half Fraser broth inoculated with bacteria was used as control. Artificially contaminated samples were incubated at $30^{\circ} \mathrm{C}$ for $24 \mathrm{~h}$.

\section{Listeria detection in processed food samples by culture}

Presence and CFU levels of L. monocytogenes in spiked food samples were measured by plate culture. For that, $1 \mathrm{ml}$ sample aliquots were taken after $24 \mathrm{~h}$ of enrichment, and were serially logarithmic diluted in PBS, spread-plated on Ottaviani Agosti Listeria agar (Reactivos para diagnóstico), and incubated at $37^{\circ} \mathrm{C}$ for $24 \mathrm{~h}$.

\section{Listeria detection in processed food samples by qualitative real-time v-PCR}

Sample aliquots of $1 \mathrm{ml}$ taken at time $0 \mathrm{~h}$ and $24 \mathrm{~h}$ were centrifuged at $800 \times \mathrm{g}$ for $2 \mathrm{~min}$, separating the food sample debris pellet. $100 \mu \mathrm{l}$ of supernatant were transferred in a new microtube, centrifuged at $14,100 \times \mathrm{g}$ for $5 \mathrm{~min}$, and the cell pellets were resuspended in $200 \mu \mathrm{l}$ of PBS and analysed by qualitative real-time v-PCR as it is depicted in the viability dye treatment section. In this case, the treatment 3 before mentioned was used since it was determined as the optimum one.

\section{Statistical analysis}

Mean values and standard deviations were calculated on the basis of two independent experiments, each performed in duplicate. Microsoft Office Excel 2010 (Microsoft Corporation, Redmond, WA, USA) was used for statistical analysis. Shapiro-Wilk test was conducted to check for the normality distribution of data, in each treatment group, considering a normality distribution at p-value $>0.05$. One-way analysis of variance (ANOVA) was used to examine differences between the treatments. Tukey's HSD test was used to identify significant differences between treatment groups. Differences and correlations were considered statistically significant at $\mathrm{p}$-value $<0.05$.

\section{RESULTS}

\section{Optimization of qualitative real-time v-PCR cell sample treatment}

The effects of the different approaches evaluated are depicted in Figure 1. As expected, PMA treatment induced a great $\Delta \mathrm{Ct}$ value (dead with PMA-dead without PMA) in dead cells suspensions with a minimum impact on live cells suspension. The results of $\Delta \mathrm{Ct}$ were: Treatment $1,14.3$ with a $95 \%$ confidence interval (CI) of (16.0-12.6), Treatment 2, 15.9 with a 95\% CI of (17.6-14.2) and Treatment 3, 18.0 with a $95 \%$ CI of (18.5-17.5). Statistical significant differences in dead cells were observed among 
the three tested treatments $(\mathrm{p}<0.05)$. Between Treatment 1 , the conventional approach, and Treatment 3 , the herein proposed new protocol, the results show a significant difference of $3.7 \mathrm{Ct}$, being the biggest difference among the treatments evaluated. Based on these results, Treatment 3 was selected for the analysis using artificially contaminated food samples.

\section{Listeria monocytogenes detection in artificially contaminated food samples}

26 food samples artificially contaminated with live and dead L. monocytogenes cells were analysed. Enrichment broth at time $0 \mathrm{~h}$ and $24 \mathrm{~h}$ were analysed by qualitative real-time PCR and v-PCR. At $24 \mathrm{~h}$, CFU levels were also evaluated by culture. The results obtained were summarized in the Table 1 . At time Oh and before enrichment culture at $30^{\circ} \mathrm{C}$, the $\mathrm{Ct}$ values of samples tested only by qualitative real-time PCR (PCR), relating to the amount of total cells spiked in samples, showed mean Ct values of 28.4 \pm 0.7 . Moreover, these samples treated with PMA (v-PCR samples) showed negative fluorescent signal detection ( $\mathrm{Ct}$ signal higher than 40$)$ in 21 samples $(80.8 \%)$ as well as in the control sample. Other 4 samples $(15.4 \%)$ showed $\mathrm{Ct}$ signal higher than the qualitative real-time PCR detection limit $(\mathrm{Ct}=36.2)$. Only in one food, the reduction was not complete as expected, with a low observed signal, Ct 35.4, very close to the detection limit. This result is probably related to the food matrix complexity (powdered milk). After 24 hours of enrichment, the mean $\mathrm{Ct}$ values of all samples without and with PMA treatment were $18.5 \pm 1.1$ and $19.2 \pm 0.9$, respectively, indicating the cell growth of live cells in the Half Fraser broth with food sample. These results show that, at this point, the presence of a high amount of dead cells does not interfere negatively in the real-time v-PCR results.

The culture-based results showed the same results for all samples and were coherent with qualitative realtime v-PCR results. Furthermore, in two of all samples tested, marinated salmon and ground pork, Listeria cell growth was not observed at $24 \mathrm{~h}$ for both analytical methods used, culture and qualitative real-time v-PCR, strengthening the suitability of v-PCR methodology.

\section{DISCUSSION}

Nowadays, there is a growing demand for rapid, sensitive, and accurate methods to detect foodborne pathogens such as L. monocytogenes. Development of rapid PCR methods that detect only viable bacteria, such as v-PCR methodology, is required in microbiological quality control in the food industry in order to shorten culture method workflow. To this end, different authors have applied v-PCR technique for accurate detection of viable L. monocytogenes cells in foods showing its suitability in the discrimination 
between live and dead L. monocytogenes cells $[5,8,16,17,18]$. However, in such approaches the elimination of false positive results in samples with high amounts of dead cells $\left(1.0 \times 10^{6}-1.0 \times 10^{8} \mathrm{CFU}\right.$ sample $^{-1}$ ) was not achieved. That suggests that further optimization of the used v-PCR procedures for Listeria detection is needed.

The first evidence of the ability of total Ct signal suppression on dead Listeria cells by v-qPCR in raw shrimp was reported by Zhang et al. 2015 [25]. These authors optimized a PMA TaqMan-based multiplex real-time PCR tool for monitoring contamination of viable $V$. parahaemolyticus and L. monocytogenes in seafood assessing the suitability of v-qPCR in samples inoculated with different concentrations of viable or dead cells. In these studies the authors used high concentration of PMA, $100 \mu \mathrm{M}$, and evaluated the vqPCR in sea foods right after cell inoculation, without pre-enrichment step in a selective broth medium.

Working in this direction, in this study, two strategies for improving qualitative real-time v-PCR for $L$. monocytogenes were assessed, aiming at false positive results suppression. The obtained results indicate that the optimal qualitative real-time v-PCR protocol, which allows maximum $\mathrm{Ct}$ signal suppression for dead L. monocytogenes cells, comprised a sample treatment with $50 \mu \mathrm{M}$ of PMA dye at $24^{\circ} \mathrm{C}$ for $30 \mathrm{~min}$ followed by double photo-activation for $15 \mathrm{~min}$ light, $10 \mathrm{~min}$ dark, and $15 \mathrm{~min}$ light. Moreover, the changing of tube throughout the procedure allowed for achieving the best results in qualitative real-time v-PCR for Listeria. Previously, we have successfully evaluated this tube change procedure in Salmonella [1] and Legionella cells [11]. Thus, demonstrating the microtube impact on the incomplete exclusion of dead cells amplification signals in v-qPCR. In that study, the suitability of tube change to remove the extracellular DNA retained in microtube walls and thereby avoiding false positive results was also evidenced. Taking to account these improvements, the change of tube procedure was introduced and assessed in these Listeria studies (Treatment 2). We found that the results obtained were better than without the tube change (Treatment 1), obtaining similar results improvements as pointed out by Agustí et al. 2016 [1]. However, in these experiments total $\mathrm{Ct}$ signal reduction from dead cells was not achieved. Considering this and in order to increase the procedure efficiency, the double treatment with PMA dye was introduced. This double dye incubation approach has been already tested by different authors [13, 20]. In the mentioned studies the PMA treatment step was performed twice. Briefly, samples were double treated with PMA and in each PMA treatment the dye was exposed to light. On the other hand, Pan and Breidt 2007 [17] tested this procedure in L. monocytogenes cells, reporting better results when samples were treated two or three times with PMA at $50 \mu \mathrm{M}$, but without complete dead cells Ct signal reduction. 
We tested this double dye methodology in our studies introducing a modification in double treated PMA methodology described by these authors by using a double light treatment without further addition of dye during the procedure. Moreover, this double photoactivation step was combined with tube change approach (Treatment 3). The results showed for first time the suitability of double light treatment in conjunction with a double change of tube in the improvement of qualitative real-time v-PCR results in $L$. monocytogenes cells detection.

Additionally, we assessed the enhanced qualitative real-time v-PCR methodology relevance for routine practice in food control. For that, 26 different food samples were spiked with different concentrations of

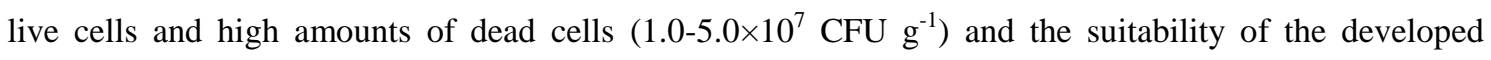
technique was evaluated before and after $24 \mathrm{hr}$ of enrichment step. The qualitative real-time v-PCR results in enrichment broth at time 0 , showed the limits of this technology for direct analysis in food samples at very high levels of dead cells. The current detection limit of the qualitative real-time PCR used in this work was internally established using Listeria DNA standard curve at $36.2 \mathrm{Ct}$ (data not shown), which corresponds to a range of 4-10 target copies per reaction according to a Poisson distribution as stated in UNE-EN ISO 7218:2007 [22]. However, under the context of a method validation the real detection limit of PCR assay for the detection of foodborne pathogen must to be estimated according to ISO method (UNE-EN ISO 16140-2016) [23]. Although levels lower than this, as 1-4 target per reaction, will not show signal in $50 \%$ of cases or less than this, the theoretical detection limit can be estimated around 39.5 Ct. Considering that, qualitative real-time PCR and v-PCR results greater than 40 also should be considered as negative. Likely, some signal beyond this range is the result of a residual unspecific amplification accumulated during 45 amplification cycles. In Table 1 and according to this criterion, at time 0 h, 5 out of 26 samples (19.2\%) still have positive signal. On the other hand, the current procedure is able to neutralize in $80.8 \%$ of cases with high levels of dead cells in artificially contaminated food samples. In future studies higher dye concentrations should be evaluated to observe if better results can be achieved with this technique.

Nevertheless, as in most cases for food pathogen the rules specify L. monocytogenes absence, therefore it does not make sense a direct analysis by PCR because up to now it is impossible a complete analysis of total bacterial DNA in a $25 \mathrm{gr}$ of food sample by PCR. For this reason, it does not make sense to focus all the efforts in evaluating the maximum neutralization capability for this application at time 0 . For $L$. monocytogenes it is a key to ensure that after the enrichment step, all PCR signals are not influenced by 
high levels of dead cells background. And based in the results obtained after the enrichment step, we can observe that, at that point and using the developed qualitative real-time v-PCR procedure, the presence of a high amount of dead cells does not interfere negatively in the qualitative real-time v-PCR results.

Formally the herein developed method has not been assessed with contamination levels close to the detection limit and/or on naturally contaminated samples, reason for this technical evaluation cannot be extrapolated directly to real samples Nevertheless, since it has been developed following a conventional enrichment step, in order to increase the cell population at levels it can be detected by PCR and culture, the obtained results suggest that the depicted sample treatment approach is suitable for Listeria detection in food samples by v-PCR. However, more validation tests using naturally contaminated food samples should be performed to strengthen the suitability of this method in routine control.

Results obtained in our study highlight that the use of qualitative real-time v-PCR methodology allows the exclusive detection of live L. monocytogenes cells in spiked food samples, minimizing the effect of false positive results. The new protocol herein proposed, in which the improvements introduced, did not add a longer times, showed good efficiencies and was able to minimize false positive results even working with high concentrations of dead cells.

\section{CONFLICT OF INTEREST}

The authors declare that they have no conflict of interest

\section{TABLES AND FIGURES}

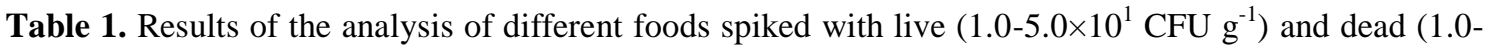
$5.0 \times 10^{7} \mathrm{CFU} \mathrm{g}^{-1}$ ) L. monocytogenes cells by qualitative real-time PCR (PCR) and v-PCR (Ct values) and culture based method (culture confirmation), before $(0 \mathrm{~h})$ and after (24h) enrichment culture at $30^{\circ} \mathrm{C}$. Samples for v-PCR were treated with $50 \mu$ M PMA. n.s., no fluorescent signal detection. >40, real-time PCR signal after 40 cycles. +/-, positive/negative plate counting results. 


\begin{tabular}{|c|c|c|c|c|c|}
\hline \multirow{2}{*}{$\begin{array}{l}\text { Time/ } \\
\text { Treatment }\end{array}$} & \multicolumn{2}{|c|}{$\mathbf{0 h}$} & \multicolumn{3}{|c|}{$24 h$} \\
\hline & PCR & v-PCR & PCR & v-PCR & $\begin{array}{c}\text { Culture } \\
\text { confirmation }\end{array}$ \\
\hline Control & 26.2 & $>40$ & 16.1 & 17.0 & + \\
\hline Meat & 25.5 & $>40$ & 24.4 & 25.9 & + \\
\hline Salad & 25.1 & 39.0 & 17.4 & 17.7 & + \\
\hline Powdered milk & 31.6 & 35.4 & 17.4 & 18.6 & + \\
\hline Ham & 28.3 & n.s & 20.4 & 20.6 & + \\
\hline Mortadella & 28.6 & 38.3 & 18.0 & 18.9 & + \\
\hline Fresh cheese & 29.1 & $>40$ & 19.5 & 21.2 & + \\
\hline Vegetable cream & 28.1 & 36.9 & 17.3 & 18.4 & + \\
\hline Lentils & 27.6 & 37.2 & 17.9 & 18.9 & + \\
\hline Marinated salmon & 30.7 & $>40$ & 27.6 & $>40$ & - \\
\hline Chicken noodle soup & 29.0 & $>40$ & 17.5 & 18.2 & + \\
\hline Chicken & 28.9 & $>40$ & 17.9 & 19.5 & + \\
\hline Champignon mushroom & 28.2 & $>40$ & 18.1 & 19.4 & + \\
\hline Vegetable couscous & 29.9 & $>40$ & 17.6 & 18.9 & + \\
\hline Green peas & 24.8 & $>40$ & 21.4 & 21.8 & + \\
\hline German sausage & 25.2 & $>40$ & 16.6 & 18.0 & + \\
\hline Rice & 26.2 & $>40$ & 16.2 & 17.9 & + \\
\hline Green cream & 28.5 & $>40$ & 20.1 & 21.5 & + \\
\hline Turkey ham & 29.3 & $>40$ & 16.6 & 18.2 & + \\
\hline Vegetal lasagne & 27.4 & $>40$ & 16.6 & 17.9 & + \\
\hline Rice with vegetables and chicken & 28.8 & $>40$ & 15.3 & 15.8 & + \\
\hline Spaghetti with tomato sauce & 29.0 & n.s & 15.4 & 16.0 & + \\
\hline Chickpea & 31.4 & n.s & 21.3 & 23.6 & + \\
\hline Green bean & 30.0 & $>40$ & 15.9 & 17.1 & + \\
\hline Turkey breast & 31.9 & n.s & 18.6 & 18.7 & + \\
\hline Ground pork & 29.2 & n.s & $>40$ & $>40$ & - \\
\hline Mozzarella cheese & 28.6 & n.s & 19.0 & 19.1 & + \\
\hline
\end{tabular}


Figure 1. Mean of $\Delta \mathrm{Ct}$ (Ct dye-treated dead cells $-\mathrm{Ct}$ non-treated dead cells) using three different v-PCR treatments. Treatment 1 , single light treatment without change of tube. Treatment 2 , single light treatment and double change of tube. Treatment 3, double light treatment and double change of tube. Error bars indicate the confidence interval from two independent assays. Statistically significant differences ( $\mathrm{p}<$ 0.05 ) between treatments are indicated by different subscript letters.

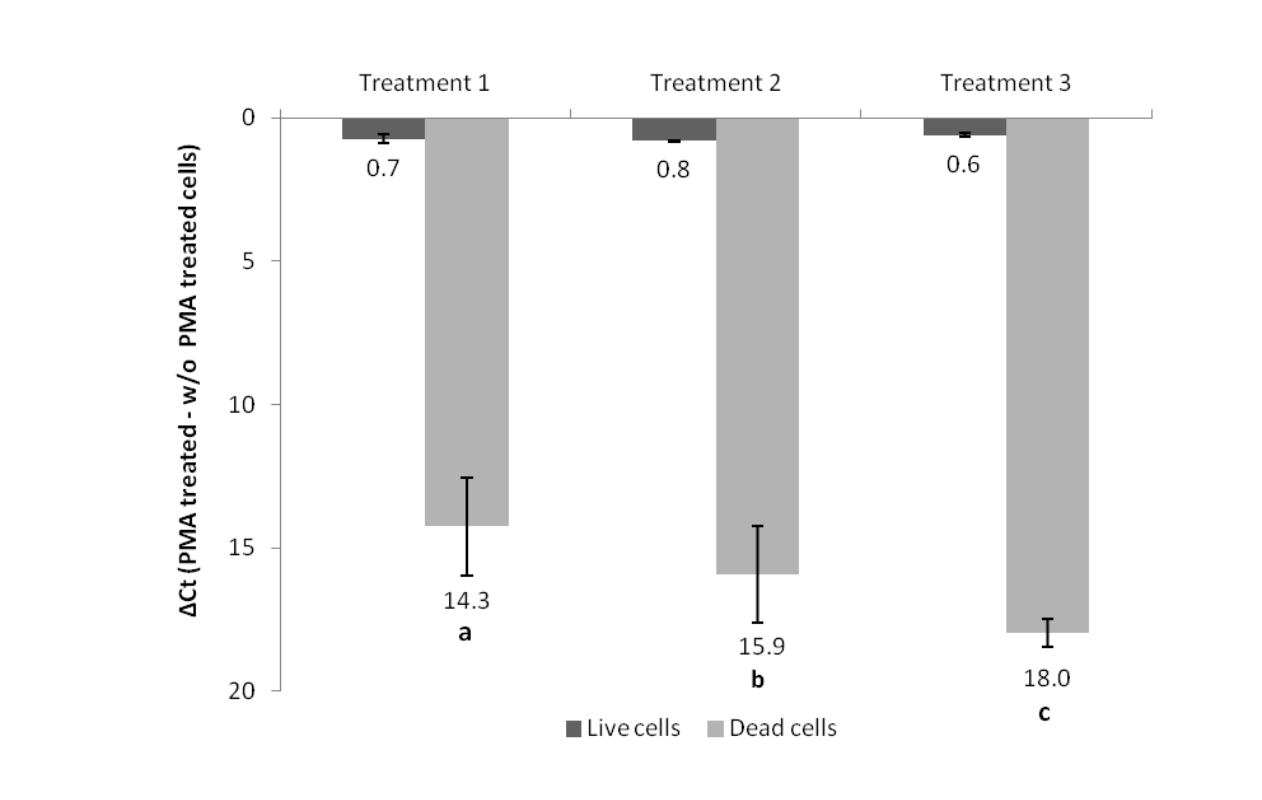

\section{REFERENCES}

1. Agustí G, Fittipaldi M, Codony F (2017) False-Positive viability PCR results: An association with microtubes. Curr Microbiol 74:377-380

2. Besnard V, Federighi M, Declerq E, Jugiau F, Cappelier JM (2002) Environmental and physicochemical factors induce VBNC state in Listeria monocytogenes. Vet Res 33:359-370

3. Chen JQ, Healey S, Regan P, Laksanalamai P, Hu Z (2017) PCR-based methodologies for detection and characterization of Listeria monocytogenes and Listeria ivanovii in foods and $\begin{array}{llllll}\text { environmental sources. Food } & \text { Science and Human Wellness. }\end{array}$ https://doi.org/10.1016/j.fshw.2017.03.001

4. D’Agostino M, Wagner M, Vazquez-Boland JA, Kuchta T, Kapriskova R, Hoorfar J, Novella S, Scortti M, Ellison J, Murray A, Fernandes I, Kuhn M, Pazlarova J, Heuvelink A, Cook N (2004) 
A validated PCR-based method to detect Listeria monocytogenes using raw milk as a food model-towards an international standard. J Food Prot 67:1646-1655

5. Elizaquivel P, Azizkhanib M, Sanchez G, Aznar R (2013) Evaluation of Zataria multiflora Boiss. essential oil activity against Escherichia coli O157:H7, Salmonella enterica and Listeria monocytogenes by propidium monoazide quantitative PCR in vegetables. Food Control 34:770776

6. Elizaquivel P, Aznar R, Sanchez G (2014) Recent developments in the use of viability dyes and quantitative PCR in the food microbiology field. J Appl Microbiol 116:1-13

7. FDA (2015) Testing methodology for Listeria species or L. monocytogenes in Environmental Samples, version 1 .

8. Ferrentino G, Tamburini S, Bath K, Foladori P, Spilimbergo S, Jousson O (2015) Application of culture-independent methods for monitoring Listeria monocytogenes inactivation on food products. Process Biochemistry 50:188-193

9. Fittipaldi M, Nocker A, Codony F (2012) Progress in understanding preferential detection of live cells using viability dyes in combination with DNA amplification. J Microbiol Methods 91:276289

10. Fittipaldi M, Codony F, Adrados B, Camper AK, Morato J (2011) Viable real-time PCR in environmental samples: can all data be interpreted directly? Microb Ecol 61:7-12

11. GenIUL Technical Note (45000146-00) (2016) Understanding the tube contribution in vPCR results. Research Gate - Research. https://doi.org/10.13140/RG.2.1.4109.2722

12. Gurresch A, Gerner W, Pin C, Wagner M, Hein I (2016) Evidence of metabolically active but non-culturable Listeria monocytogenes in long-term growth at $10^{\circ} \mathrm{C}$. Res Microbiol 167:334343

13. Kralik P, Nocker A, Pavlik I (2010) Mycobacterium avium subsp. paratuberculosis viability determination using F57 quantitative PCR in combination with propidium monoazide treatment. Int J Food Microbiol 141:S80-S86

14. Law JF, Ab Mutalib NS, Chan KG, Lee LH (2015) An insight into the isolation, enumeration, and molecular detection of Listeria monocytogenes in food. Front Microbiol 6:1227 
15. Law JF, Ab Mutalib NS, Chan KG, Lee LH (2014) Rapid methods for the detection of foodborne bacterial pathogens: principles, applications, advantages and limitations. Front Microbiol 5:770

16. Nkuipou-Kenfack E, Engel H, Fakih S, Nocker A (2013) Improving efficiency of viability-PCR for selective detection of live cells. J Microbiol Methods 93:20-24

17. Pan Y, Breidt F (2007) Enumeration of viable Listeria monocytogenes cells by real-time PCR with propidium monoazide and ethidium monoazide in the presence of dead cells. Appl Environ Microbiol 73:8028-8031

18. Rudi K, Naterstad K, Drømtorp SM, Holo H (2005) Detection of viable and dead Listeria monocytogenes on gouda-like cheeses by real-time PCR. Lett Appl Microbiol 40:301-306

19. Scallan E, Hoekstra RM, Angulo FJ, Tauxe RV, Widdowson MA, Roy SL, Jones JL, Griffin PM (2011) Foodborne illness acquired in the United States-major pathogens. Emerg Infect Dis 17: 7-15

20. Takahashi H, Gao Y, Miya S, Kuda T, Kimura B (2016) Discrimination of live and dead cells of Escherichia coli using propidium monoazide after sodium dodecyl sulfate treatment. Food Control 71:79-82

21. UNE-EN ISO 11290-1 (2017)-Microbiology of the food chain-Horizontal method for the detection and enumeration of Listeria monocytogenes and other Listeria spp.-Part 1: Detection method.

22. UNE-EN ISO 7218:2007-Microbiology of food and animal feeding stuffs-General requirements and guidance for microbiological examinations.

23. UNE-EN ISO 16140-2:2016-Microbiology of the food chain-Method validation. Part 2: Protocol for the validation of alternative (proprietary) methods against a reference method.

24. Zeng D, Chen Z, Jiang Y, Xue F, Li B (2016) Advances and challenges in viability detection of foodborne pathogens. Front Microbiol 7:1833

25. Zhang Z, Liu H, Lou Y, Xiao L, Liao C, Malakar PK, PanY, ZhaoY (2015) Quantifying viable Vibrio parahaemolyticus and Listeria monocytogenes simultaneously in raw shrimp. Appl Microbiol Biotechnol 99:6451-6462

26. Zhao X, Zhong J, Weil C, Lin CW, Ding T (2017) Current perspectives on viable but nonculturable state in foodborne pathogens. Front Microbiol 8:580 